\title{
JOURNAL.RU
}

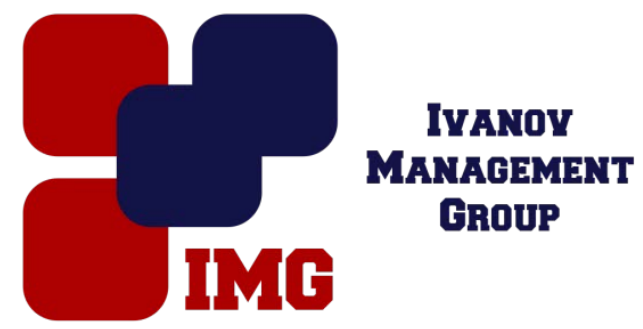

Смирнова И.И.

Институт подготовки государственных и мунищипальных служащих Академии ФСИН России

Рязань, Россия

doi: 10.18411/lj-31-03-2017-1-15

idsp 000001:lj-31-03-2017-1-15

\section{История регулирования алиментных обязательств второй очереди в отечественном семейном законодательстве}

\begin{abstract}
Аннотация
Алиментные обязательства второй очереди позволяют обеспечить материальную поддержку незащищенным категориям населения в том случае, когда взыскание содержания с самых близких родственников не представляется возможным. Однако, несмотря на то, что отечественному семейному законодательству, регламентирующему алиментные обязательные правоотношения второй очереди, насчитывается ни один десяток лет, большая часть граждан нашей страны не знает о возможности взыскания алиментов с других членов семьи, что приводит к невостребованности указанного права. В связи с этим вопрос исторического становления, регулирования данного института права является очень актуальным как для научного сообщества, так и для обычных обывателей.

Ключевые слова: алименты, алиментные обязательства, вторая очередь, история.

Отечественному семейному законодательству, регламентирующему алиментные обязательные правоотношения второй очереди, насчитывается ни один десяток лет, поэтому вопрос исторического становления, регулирования данного института права является очень важной ступенью нашего исследовании. Ведь без аналитического взгляда на путь, пройденный указанным институтом, на его становление обойтись не только нельзя, но и методологически ошибочно.

В процессе научного познания всегда необходимо изучить, как возник, развивался, устанавливался тот или иной правовой институт. К тому же, анализ ранее действовавшего законодательства, регулирующего алиментные обязательства второй очереди, очень важен для поиска возможных путей
\end{abstract}


дальнейшего совершенствования изучаемого объекта, для формулировки предложений по повышению его эффективности.

Основы становление семейного права на Руси, в том числе и зачатки алиментного обязательства, можно найти на самых ранних этапах развития отечественного права.

Традиция заботы о слабых, незащищенных слоях общества зародилась еще в эпоху существования древнеславянских общин, которая датируется примерно VI IX вв. н.э.

Наши предки на той, начальной стадии общественного развития вели общинно-родовой образ жизни. Они не знали семьи, они знали только род, представляющий собой всю совокупность степеней родства: от самых близких до самых дальних.

В то время женщины не обладали наследственными правами наравне с мужчинами, поэтому возник обычай (обряд) «приданного», согласно которому лица, исключившие незамужнюю девушку из числа наследников, обязаны были наделить ее, при вступлении последней в брак, определенным имуществом (даром). Причем, участие в сборе приданного принимали ни только родители (мать и отец), но и остальные члены рода, в первую очередь братья, обладающие правом наследования. Таким образом, как отмечает М.А. Данилян, «приданное» выступает прообразом алиментных обязательств как первой и, что немаловажно, второй очереди, потому что порождает имущественные отношения не только между родителями и детьми, но и между родственниками в целом.

Также, рассуждая о зачатках становления алиментных обязательных правоотношений второй очереди, нельзя не упомянуть традицию поддержки пожилых людей, которая повелевала оказывать роду (родственникам) всяческую поддержку старикам, «окончательно впадшим в дряхлость». И только если род был не в состоянии оказать подобную помощь в полной мере, то заботу о стариках брала на себя община.

На смену языческой эпохе, где вопрос алиментных обязательств других членов семьи регламентировался обычаями и традициями, приходит эпоха христианства (X-XV вв.), и указанные семейные правоотношения переходят в введение церкви.

В Кормчей книге (XII в.), являвшейся источником церковного и светского права, впервые было отражено понятие «брак» как «...тайна от Христа Бога установленная, во умножение рода человеческого и в воспитание чад к славе Божьей в нерушимый союз любви и дружества и во взаимную помощь». Стало быть, уже тогда закрепляется одно из основных положений современного семейного законодательства, которое выражается в построение семейных отношений на основе «взаимопомощи и ответственности перед семьей всех ее членов» (п.1 ст.1. СК РФ).

Что касается материального содержания одних членов семьи другими, то его в религиозную эпоху регулировал первый сборник правовых норм - Русская правда (XII-XV вв.), на ст. 99 которого хочется обратить особое внимание. 
Данная статья устанавливала обязанность ближайшего «родича» взять опеку над детьми после смерти их отца, в случае если мать этих детей вновь выходила замуж, т.е. ближайший родственник должен был содержать, опекать и заботится о вверенных ему детях.

Если провести аналогию с нашим современным законодательством, то можно говорить о том, что из этого положения Русской правды впоследствии развились нормы об алиментных обязанностях второй очереди, а именно, обязанность совершеннолетних братьев и сестер содержать своих несовершеннолетних или нетрудоспособных совершеннолетних братьев и сестер (ст. 93 СК РФ) и обязанность дедушки и бабушки содержать своих несовершеннолетних или нетрудоспособных совершеннолетних внуков (ст. 94 СК PФ).

В XV-XVIII вв. брачно-семейные отношения рассматривались как церковным, так и светским правом. Однако, стоит отметить, что нормы, регулирующие предоставление содержания другим членами семьи, полностью отсутствовали.

XIX в. стал важной вехой в истории развития законодательства дореволюционной России.

К 1832 г. под руководством Михаила Михайловича Сперанского был изготовлен, а Манифестом Николая I от 31 января (12 февраля) 1833 г. - объявлен действующим источником права с 1 (13) января 1835 г., 15-томный «Свод законов Российской империи» (далее - С3 РИ). Он представлял собой официальное собрание всех, без исключения, действующих законодательных актов имперской России.

Данный свод законов закреплял понятие семья «как союз лиц, связанных браком, и лиц, от них происходящих...», т.е. субъективный состав семьи был достаточно ограничен (узок) и включал в себя только родителей, детей и супругов (бывших супругов).

Законодатель того времени признавал право на содержание только за детьми и родителями. Однако, несмотря на это, указанный источник права включал также любопытные для наших изысканий статьи.

Так, том X Свода законов Российской империи содержит главу, разъясняющую понятие и содержание родства.

Родственниками признавались лица, происходящие или друг от друга, или от общего родоначальника (гл. 3, ст. 196 С3 РИ). Близость родства определялась линиями (прямыми и боковыми, восходящими и нисходящими) и степенями (гл. 3 , ст. 197 - 200 СЗ РИ).

Главным образом наш научный интерес составляют именно степени родства, которую законодатель определял при помощи подсчета количества «необходимых рождений». Таким образом, к первой степени родства относили отца, сына, а ко второй - дедушку, брата. Хотя, как уже говорилось выше, в то время обязанность содержания возлагалась только на родственников первой степени, уже выделялись в отдельную группу и другие ближайшие родственники, 
которые в последствии и легли в основу алиментных правоотношений второй очереди.

Начиная с периода Октябрьской революции 1917 г. отечественное семейное законодательство претерпевает существенные изменения, потребность в которых, в первую очередь, была продиктована самой общественностью, ее новыми взглядами на проблемы построения и функционирования института семьи.

Постреволюционное реформирование семейного права началось уже в декабре 1917 г. и ознаменовалось принятием на сессии Всероссийского центрального исполнительного комитета (ВЦИК) 16 сентября 1918 г. первого в истории России кодекса: «Кодекс законов об Актах гражданского состояния, брачном, семейном и опекунском праве» (далее - КЗАГС).

Именно этот нормативно-правовой акт впервые на законодательном уровне закреплял обязанность алиментировать не только нуждающихся и нетрудоспособных родителей, детей, супругов (алиментные обязательства первой очереди), но и других родственников (алиментные обязательства второй очереди). О чем прямо говорилось в ст. 172-173 КЗАГС, в соответствии с которыми нуждающиеся (т.е. не имеющие прожиточного минимума) и нетрудоспособные родственники по прямой восходящей и нисходящей линиям, в том числе полнородные и неполнородные сестры и братья имели право получать содержание от своих «состоятельных родственников» в том случае, если не представлялось возможным получить его от родителей, детей или супруга в связи с их несостоятельностью либо отсутствием.

Стоит отметить, что нетрудоспособными признавались лица, недостигшие совершеннолетия (18 лет), мужчины, достигшие 55 лет и женщин достигшие 50, а также инвалиды I -III групп (ст. 113 КЗАГС).

В том случае, если алиментообязанные лица не желали содержать своего нуждающегося, нетрудоспособного родственника, последний имел возможность обратится с «заявлением о выдаче содержания» в «Отдел Социального Обеспечения при Губернском Совете Депутатов» по месту жительства алиментообязанного лица (ответчика) для восстановления своих прав. Такое заявление не облагалось пошлиной и подавалось истцом в письменной форме лично или посредством почты, а также в устной форме (с занесением в протокол) (ст. 108-109 КЗАГС). После чего Отдел социального обеспечения вызывал «в свое присутствие» заявителя и ответчика или, для удобства, вел переписку с ними по почте для установления наличия (отсутствия) обстоятельств, обосновывающих заявленное требование. И только окончательно убедившись в справедливости обращения, выносил постановление о выдаче содержания, о его размере и форме в публичном заседании, но не позднее одного месяца со дня подачи заявления (ст. 110-112 КЗАГС). Жалобы на постановления Отдела Социального Обеспечения рассматривал местный суд без ограничения срока исковой давности (ст. 116 КЗАГС). 
Если алиментообязанных родственников было несколько, то они отвечали по алиментному обязательству в равных долях при условии, что суд не устанавливал иное (ст.175 КЗАГС).

Исходя из проведенного выше анализа Кодекса законов об Актах гражданского состояния, брачном, семейном и опекунском праве 1918 г., можно говорить о том, что большая часть закрепленных в нем норм, регулирующих алиментные обязательства второй очереди, нашло свое отражение в ныне действующем Семейном кодексе Российской Федерации. Однако, нельзя не упомянуть и существенных различиях в данных нормативно-правовых актов по отношению друг от другу.

Возьмем, к примеру, ст. 179 КЗАГС, которая устанавливала право алиментополучателя, даже после смерти алиментодателя, на содержание из оставшегося после него имущества, т.е. алиментные правоотношения не носили строго личностный характер. Хотя для нынешнего семейного законодательства смерть лица, обязанного выплачивать алименты, является не только основанием для прекращения данного обязательства (ст. 120 СК РФ), но и основным признаком института алиментирования.

Не вызывает сомнение тот факт, что все приведенные нами положения Кодекса 1918 г. носили новаторский характер. Они значительно облегчали обеспечение и защиту прав неимущих граждан на получение материальных средств от своих родственников путем закрепления алиментных обязательных правоотношений второй очереди, но, в то же время содержали определенные недостатки, упущения со стороны законодательства.

Одним таким недостатком являлось отсутствие четко определенного круга лиц, входивших в субъектный состав алиментных обязательств других членов семьи. В связи с чем, обязанность по материальному содержанию могла быть возложена на всех родственников по прямой восходящей и нисходящей линиям, а именно, на: дедушек, бабушек, прадедушек, прабабушек, внуков и правнуков, что, по нашему мнению, являлось в корне неправильно.

Следующим этапом развития алиментных обязательств других членов семьи стало введение в действие с 1 января 1927 г. Кодекса законов о браке, семье и опеке РСФСР (далее - КЗоБСО РСФСР).

Согласно статьям 54-55 Кодекса законов о браке, семье и опеке РСФСР, «нуждающиеся несовершеннолетние братья и сестры имели право на содержание от своих братьев и сестер», «нетрудоспособные и нуждающиеся дедушка и бабушка были вправе получать содержание от своих внуков», «нуждающиеся несовершеннолетние или нетрудоспособные внуки имели право на получение содержания от дедушки или бабушки» лишь в том случае, если те обладали «достаточными средствами», а взыскать алименты с родителей, детей или супругов не было возможности, «ввиду отсутствия или несостоятельности последних».

Приведенные выше статьи позволяют на говорить о том, что круг алиментодателей и алиментополучателей второй очереди был уточнен, и 
обязанность по содержанию уже не возлагалась на прадедушек, прабабушек, правнуков и правнучек.

К алиментообязанным законодатель относил братьев и сестер, бабушек и дедушек, а также внуков, обладающих достаточными для уплаты алиментов средствами. А правом требовать предоставления содержания обладали нуждающиеся несовершеннолетние братья и сестры, нуждающиеся несовершеннолетние или нетрудоспособные внуки, а также нетрудоспособные и нуждающиеся дедушки и бабушки.

Что интересно, правом требования уплаты алиментов от братьев и сестер теперь обладали только несовершеннолетние нуждающиеся братья и сестры. Законодатель исключал нетрудоспособность братьев и сестер из условий, необходимых для получения ими права на содержание от других членов семьи. При чем у остальных алиментополучателей второй очереди данное условие сохранялось.

В конце 1928 г. законодатель вносит поправки в действующий на тот момент кодекс и значительно расширяет субъектный состав алиментных обязательств второй очереди.

Именно тогда были впервые включены положения, регулирующие алиментные правоотношения между лицами, не состоявшими в родстве: отчимом (мачехой) и пасынком (падчерицей), а также между фактическим воспитателем и его воспитанником.

Законодательное закрепление данных семейных правоотношений являлось, на то время, крайне необходимой мерой. В первую очередь это было связанно с тем, что до того момента институты фактического брака и фактического воспитания существовали номинально (не требовали юридического оформления) и не всегда выполняли свое назначение в полной мере, так как чаще всего указанные выше лица, не имея никаких юридически закрепленных обязательств, элементарно отказывались материально поддерживать (содержать) друг друга.

В соответствии со статьями 42.1 и 42.2 КЗоБСО РСФСР (в редакции 1928 г.), на отчима (мачеху) или фактического воспитателя возлагалась обязанность по содержанию несовершеннолетних и нуждающихся нетрудоспособных пасынка (падчерицы) или воспитанника соответственно. Однако наступали данные обязательства только в случае смерти или финансовой несостоятельности родителей, детей или супругов лица, имеющего право на получение алиментов.

В свою очередь, совершеннолетние трудоспособные пасынки, падчерицы и воспитанники также были обязаны предоставить содержание нуждающимся нетрудоспособным отчиму (мачехе), фактическому воспитателю при условии, что они находились на иждивении последних не менее 10 лет.

При всем при этом, алиментная обязанность возлагалась на лица, не состоящие в родстве, вне зависимости от того обладали ли они необходимыми средствами или нет. 
Последним кодексом советской эпохи, регулирующим брачно-семейные правоотношения, стал Кодекс о браке и семье РСФСР (далее - КОБС РСФСР), вступивший в силу 1 ноября 1969 г.

Здесь впервые алиментные обязанности других членов семьи были выделены в отдельную главу 10.

КОБС РСФСР 1969 г. расширил алиментные обязательства братьев и сестер, включив нетрудоспособность совершеннолетних, нуждающихся братьев и сестер в условия для получения ими права на содержание. Которую, как мы отмечали ранее, предыдущий КЗоБСО РСФСР 1927 г. исключал .

Изменения коснулись также алиментных правоотношений между отчимом (мачехой) и пасынком ( падчерицей). Так, согласно ст. 80 КОБС РСФСР, отчим и мачеха обязаны были содержать только несовершеннолетних пасынков и падчериц. А они, в свое очередь могли быть освобождены судом от уплаты алиментов отчиму или мачехе, если те не выполняли своих обязанностей по воспитанию надлежащим образом (ч. 2 ст. 81 КОБС РСФСР) или воспитывали их менее пяти лет, а не десяти, как устанавливалось в ранее действовавшем кодексе (ч. 2 ст. 81 КОБС РСФСР).

С алиментными правоотношения между фактическими воспитателями и воспитанниками дела обстояли несколько иначе.

Лица, взявшие к себе на постоянное воспитание детей на постоянное воспитание, были обязаны содержать как несовершеннолетних, так и нетрудоспособных совершеннолетних нуждающихся воспитанников (ст. 85 КОБС РСФСР). А воспитанники обязаны были содержать своих фактических воспитателе не зависимо от того, как и в течение какого срока последние осуществляли принятые на себя обязанности по воспитанию (ст. 86 КОБС РСФСР).

В настоящее время в нашей стране действует Семейный кодекс Российской Федерации, который был принят Государственной думой 8 декабря 1995 г. Указанный нормативно-правовой акт также внес ряд изменений в регулирование алиментных обязательств других членов семьи, содержащихся в гл. 15.

Так, например, законодатель полностью исключил обязанность отчима и мачехи по содержанию пасынков и падчериц, а также обязанность фактических воспитателей по содержанию воспитанников.

Семейный кодекс РФ также предусматривает возможность освобождения воспитанников от обязанности содержать фактических воспитателе при условии, что последние осуществляли содержание и воспитание ненадлежащим образом и (или) менее пяти лет (ст. 96 СК РФ), в отличие от предыдущего законодательного акта.

Таким образом, проведенный нами исторический анализа дает возможность сделать следующий вывод: алиментные обязательства второй очереди прошли долгий путь развития, каждый этап которого сопровождался внесением все новых и новых изменений: увеличивался понятийный аппарат данного правового института, постепенно уточнялся его субъектный состав; изменялись основания 
для взыскания и порядок уплаты алиментов. Но задача правового регулирования алиментных обязательств других членов семьи, да и алиментных правоотношений в целом, всегда оставалась и остается по сей день неизменной и заключается в защите и поддержке социально незащищенных, малоимущих слоев населения.

\section{Литература}

1. Семейный кодекс Российской Федерации. - М. : «Омега-М», 2015. - 57 с.

2. Данилян, М. А. К вопросу об истории развития алиментного законодательства в России // Современное право, 2012. - $\neg$ № 4. - $\neg$ С. 157-ᄀ161.

3. Осина Ю.Ю. Правовые аспекты становления семейного права и развития алиментных отношений в дореволюционной // Юридическая мысль, 2009. - С.95-98.

4. Спицина Т.В. Этапы развития законодательного регулирования алиментных обязательств других членов семьи // Современное право. $-\neg \neg$ 2012. $-\neg \neg$ № 11. $\neg-\neg$ С. $138-\neg 140$.

5. Холостова, Е. И. История социальной работы в России. - М. : «Дашков и Кํ», 2013. $282 \mathrm{c}$.

6. Шершеневич Г. Ф. Учебник русского гражданского права (по изд. 1907 г.). - М., 1995. $-461 \mathrm{c}$. 